\title{
ANALISIS TINGKAT KEBUTUHAN AIR BERSIH WILAYAH PERKOTAAN KOTA WANGI-WANGI KABUPATEN WAKATOBI
}

\author{
Agusman \\ Program Studi Teknik Sipil, Fakultas Teknik, \\ Universitas Muhammadiyah Buton, Jl. Betoambari No. 36 Baubau. \\ E-mail:agus_man8233@yahoo.co.id
}

\begin{abstract}
Abstrak
Tujuan penelitian ini untuk mengetahui Tingkat Kebutuhan Air Bersih Wilayah Perkotaan Kota Wangi-Wangi Kabupaten Wakatobi. Hasil penelitian menunjukan bahwa kebutuhan air bersih daerah pelayanan Kota Wangi-Wangi Kabupaten Wakatobi tahun 2028 menurut jumlah penduduk sebesar 31,82 liter/detik, Kebutuhan air bersih menurut prediksi masing-masing jenis pelanggan adalah 15,48 liter/detik. Kekurangan debit pompa produksi yang dibutuhkan untuk memenuhi kebutuhan air bersih wilayah Kota Wangi-Wangi Kabupaten Wakatobi pada tahun 2028 adalah sebesar 2,48 liter/detik.
\end{abstract}

Kata kunci: debit, air bersih, perkotaan.

\begin{abstract}
The purpose of this study is to determine the level of urban water needs of Wangi-Wangi City Wakatobi. The results showed that the needs of clean water service area Wangi-Wangi City Wakatobi regency in 2028 according to the number of residents of 31.82 liters / second, The need for clean water according to the predictions of each type of customer is 15.48 liters / sec. Disadvantages of pump production discharge needed to meet the needs of clean water area Wangi-Wangi City Wakatobi regency in 2028 amounted to 2.48 liters / sec.
\end{abstract}

Keywords: discharge, clean water, urban areas. 


\section{SANG PENCERAH}

Volume 3, Nomor 2, Agustus 2017, Hlm. 1-10

Agusman: Analisis Tingkat Kebutuhan Air Bersih Wilayah ...

\section{Pendahuluan}

Seiring dengan semakin bertambahnya jumlah penduduk di kota Wangi-Wangi Kabupaten Wakatobi kebutuhan akan ketersediaan air bersih juga akan semakin meningkat. Penelitian-penelitian di lakukan untuk menemukan solusi dari masalah ini. Air merupakan kebutuhan setiap makhluk hidup yang ada di muka bumi ini sehingga keberadaannya pun harus di jaga baik dari segi kuantitas maupun kualitas air tersebut.

Dalam memenuhi kebutuhan masyarakat akan air bersih, Pemerintah kota Wangi-Wangi melalui PDAM (Perusahaan Daerah Air Minum) dan programprogramnya telah berupaya semaksimal mungkin untuk mengatasi masalah publik ini, namun realisasinya masih banyak masyarakat yang mengeluh masalah air bersih. Ada yang mengeluh karna di rumahnya belum ada saluran PDAM, ada pula yang mengeluh karna air dari PDAM keruh, berbau, dan sebagainya. Peningkatan aktivitas industri dermaga, pertanian, permukiman penduduk, transportasi, dan lain-lainnya, selain memberikan dampak positif sebagai tempat pendapatan ekonomi masyarakat, juga memberikan indikasi adanya dampak negative, yaitu seperti berupa limbah cair dan padat (baik organik maupun non organik). Limbah cair seperti minyak hasil pembuangan dari kapal baik yang berlabuh maupun yang melakukan pengedokan kapal, begitu juga limbah cair dan padat yang berasal dari industri permukiman rumah tangga, dan lain-lainnya yang dapat mencemari sumber air bersih.

Air merupakan salah satu sumberdaya alam yang sangat penting bagi kehidupan manusia, baik untuk memenuhi kebutuhan hidup sehari-hari maupun untuk kepentingan lainnya seperti pertanian dan indutri. Oleh karena itu keberadaan air dalam masyarakat perlu dipelihara dan dilestarikan bagi kelangsungan kehidupan. Air tidak dapat dipisahkan dengan kehidupan, tanpa air tidaklah mungkin ada kehidupan.

Di Indonesia pelayanan air bersih dalam skala besar masih terpusat di daerah perkotaan, dan dikelola oleh Perusahan Daerah Air Minum (PDAM) kota yang bersangkutan. Pelayanan penyediaan air bersih secara nasional masih jauh dari mencukupi dan dapat dikatakan relatif kecil yakni 16,08\% (1995). Untuk daerah yang belum mendapatkan pelayanan air bersih dari PAM umumnya mereka menggunakan air tanah (sumur), air sungai, air hujan, air sumber (mata air) dan lainnya.

Kabupaten Wakatobi merupakan salah satu kabupaten di Provinsi Sulawesi Tenggara, Indonesia. Salah satu permasalahan pada kabupaten Wakatobi sekarang adalah tidak terpenuhinya persediaan air minum pada wilayah perkotaan. Pada kawasan ini terdapat dua kecamatan yaitu Kecamatan Wangi-wangi dan Kecamatan Wangi-wangi Selatan. Pada kawasan Wangi-wangi terdapat beberapa desa dimana salah satu desa merupakan kawasan yang akan direncanakan untuk pembangunan instalasi pengolahan air bersih.

Tingginya laju pembangunan kota, banyaknya sumur bor, dan pemompanan dalam skala besar bisa menjadi salah satu penyebab mempercepat penurunan permukaan tanah. Berdasarkan uraian di atas, fokus penelitian ini adalah bagaimanakah Tingkat Kebutuhan Air Bersih Wilayah Perkotaan Kota WangiWangi Kabupaten Wakatobi?

Tujuan penelitian ini untuk mengetahui Tingkat Kebutuhan Air Bersih Wilayah Perkotaan Kota Wangi-Wangi Kabupaten Wakatobi. 


\section{SANG PENCERAH}

Volume 3, Nomor 2, Agustus 2017, Hlm. 1-10

Agusman: Analisis Tingkat Kebutuhan Air Bersih Wilayah ...

\section{Metode Penelitian}

Penelitian yang dilakukan di Kota Wangi-Wangi Kabupaten Wakatobi ini termasuk jenis penelitian deskriptif kualitatif. Dikatakan demikian karena dalam penelitian ini, informasi dan data dikumpulkan melalui responden PDAM Kontamale dan mengumpulkan data-data yang diperlukan dan survey langsung ke sumber air untuk mengetahui ketersediaan sumber air.

\section{Waktu dan Tempat Penelitian}

Penelitian terletak di Wilayah Perkotaan Wangi-Wangi Kabupaten Wakatobi. Sedangkan waktu penelitian ini akan dilaksanakan mulai bulan Februari Juli 2017.

\section{Variabel Penelitian}

Variabel yang diperlukan dalam penelitian ini adalah jumlah pelanggan, jenis-jenis pelanggan, penduduk Kecamatan Wangi-Wangi dan debit yang dibutuhkan untuk memenuhi kebutuhan pelanggan air PDAM Kontamale.

\section{Teknik Pengumpulan Data}

\section{Tahap Persiapan}

Tahap persiapan yang dimaksud untuk mempermudah jalannya penelitian, seperti: pengumpulan data, analisis, dan penyusunan laporan. Tahap persiapan ini meliputi:

a. Studi Pustaka

Studi pustaka dimaksudkan untuk memberikan arahan dan wawasan sehingga mempermudah dalam pengumpulan data, analisis maupun dalam penyusunan laporan.

b. Observasi lapangan

Observasi lapangan dilakukan
untuk mengetahui dimana
lokasi/tempat dilakukannya
pengambilan data yang diperlukan
dalam penyusunan hasil penelitian.

\section{Pengumpulan Data}

Metode pengumpulan data dalam kasus ini diperoleh melalui studi literatur serta menggunakan data yang dimiliki oleh instansi terkait, dalam hal ini adalah Kecamatan Wangi-Wangi PDAM Kontamale. Adapun data tersebut:

1. Data jumlah penduduk Kecamatan Wangi-Wangi selama 5 tahun terakhir;

2. Data pelanggan menurut jenis-jenis pelanggan selama 5 tahun terakhir;

3. Data kebutuhan air bersih untuk pelanggan Wangi-Wangi;

\section{Teknik Analisis Data}

Pada tahap analisis dilakukan dengan menghitung data yang ada untuk mencari laju perubahan dari masing-masing elemen dan mengetahui kebutuhan air bersih. Data yang diperlukan dari segi kuantitas yaitu penambahan pelanggan PDAM menurut variabel-variabelnya selama 5 tahun terakhir, kemudian data tersebut dianalisis menggunakan rumus-rumus untuk mencari kebutuhan air bersih periode 10 tahun mendatang.

\section{Pembahasan}

\section{Prediksi Jumlah Penduduk}

Perkiraan jumlah penduduk Kota Wangi-Wangi dianalisisi dengan menggunakan 3 metode, yaitu Metode Geometrik, Metode Aritmatik dan Metode Regresi Linear, untuk memperoleh keakuratan jumlah penduduk. Selanjutnya dipilih korelasi (r) yang lebih besar. Data jumlah penduduk yang didapat dari PDAM Kota Wangi-Wangi sejak tahun 2013 sampai 2017, dengan prediksi hingga tahun 2028. Dibawah ini diperhitungkan ketiga Metode tersebut. 


\section{SANG PENCERAH}

Volume 3, Nomor 2, Agustus 2017, Hlm. 1-10

Agusman: Analisis Tingkat Kebutuhan Air Bersih Wilayah ...

Tabel 1 Data Penduduk Kota Wangi-Wangi Selama 5 Tahun Terakhir

\begin{tabular}{|c|c|c|c|}
\hline \multirow{2}{*}{ Tahun } & \multirow{2}{*}{$\begin{array}{c}\text { Jumlah } \\
\text { Penduduk }\end{array}$} & \multicolumn{2}{|c|}{ Pertambahan } \\
\hline & & Jiwa & $\%$ \\
\hline 2013 & 44.720 & - & - \\
\hline 2014 & 44.915 & 195 & 0,436 \\
\hline 2015 & 45.192 & 277 & 0,617 \\
\hline 2016 & 45.421 & 229 & 0,507 \\
\hline \multirow[t]{2}{*}{2017} & 45.513 & 91 & 0,200 \\
\hline & Jumlah & 792 & 1,760 \\
\hline
\end{tabular}

Sumber : Hasil Analisis

Rerata pertambahan penduduk dari tahun 2013 - 2017 adalah:

$$
\begin{aligned}
\mathrm{K}_{\mathrm{a}}= & \frac{P_{03}-P_{o 7}}{2013-2017} \\
\mathrm{~K}_{\mathrm{a}}= & \frac{45.513-44.720}{4} \\
\mathrm{~K}_{\mathrm{a}}= & 198,25 \text { Jiwa / tahun }
\end{aligned}
$$

Persentase pertumbuhan penduduk rerata per tahun:

$$
\begin{aligned}
\mathrm{R} & =\frac{\text { Jumlah \% Pertambahan }}{\text { Tahun } \mathrm{n}-\text { Tahun }_{\mathrm{o}}} \\
\mathrm{R} & =\frac{1,760 \%}{4} \\
\mathrm{r} & =0,44 \%
\end{aligned}
$$

Dengan bertolak dari data penduduk tahun 2013 menghitung pertambahan jumlah penduduk dari tahun 2013-2017 dengan menggunakan metode Geometrik, Metode Aritmatik, dan Metode Regresi Linear.

\section{Metode Geometrik}

$$
\begin{aligned}
& \mathrm{P}_{\mathrm{n}}=\mathrm{P}_{\mathrm{o}} \times(1+\mathrm{r})^{\mathrm{n}} \\
& \mathrm{P}_{07}=\mathrm{P}_{03} \times(1+0,0044)^{(07-03)} \\
& \mathrm{P}_{07}=\mathrm{P}_{03} \times(1,0044)^{4} \\
& \mathrm{P}_{03}=\mathrm{P}_{07} /(1,0044)^{4} \\
& \mathrm{P}_{03}=45.513 /(1,0044)^{4} \\
& \mathrm{P}_{05}=44720,71 \text { jiwa }
\end{aligned}
$$

\section{Metode Aritmatik}

$$
\begin{aligned}
\mathrm{K}_{\mathrm{a}}= & \begin{array}{c}
P_{2}-P_{1} \\
-----T_{1} \\
T_{2}-T_{1} \\
45.513-44.720
\end{array} \\
\mathrm{~K}_{\mathrm{a}}= & \text {--2017 - } 2013
\end{aligned}
$$

$$
\begin{aligned}
& \mathrm{K}_{\mathrm{a}}=198,25 \text { jiwa } / \text { tahun } \\
& \mathrm{P}_{\mathrm{n}}=\mathrm{P}_{07}=45.513 \text { jiwa } \\
& \mathrm{P}_{\mathrm{n}}=\mathrm{P}_{03}+\mathrm{Ka} \times\left(\mathrm{T}_{\mathrm{n}}-\mathrm{T}_{\mathrm{o}}\right) \\
& \mathrm{P}_{03}=45.513-198,25 \times(2017-2013) \\
& \mathrm{P}_{03}=44.720 \text { jiwa }
\end{aligned}
$$

3. Metode Regresi Linear

$$
\begin{aligned}
& \hat{y}=a+b x \\
& a=\frac{\sum Y \cdot \sum X^{2}-\sum X \cdot \sum X Y}{n \cdot \sum X^{2}-\left(\sum X \cdot Y\right)^{2}} \\
& b=\frac{n \cdot \sum X Y-\sum X \cdot \sum Y}{n \cdot \sum X^{2}-\left(\sum X\right)^{2}}
\end{aligned}
$$

Tabel 2 Metode Regresi Linear

\begin{tabular}{lllll}
\hline Tahun & $\begin{array}{l}\text { Tahun ke } \\
(\mathbf{X})\end{array}$ & $\begin{array}{l}\text { Jumlah } \\
\text { Penduduk }\end{array}$ & X. Y & $\mathbf{X}^{2}$ \\
\hline 2013 & 1 & 44.720 & 44.720 & 1 \\
2014 & 2 & 44.915 & 89.830 & 4 \\
2015 & 3 & 45.192 & 135.576 & 9 \\
2016 & 4 & 45.421 & 181.684 & 16 \\
2017 & 5 & 45.513 & 227.565 & 25 \\
\hline Jumlah & $\mathbf{1 5}$ & $\mathbf{2 2 5 . 7 6 1}$ & $\mathbf{6 7 9 . 3 7 5}$ & $\mathbf{5 5}$ \\
\hline
\end{tabular}

Sumber : Analisi Data

Dengan menggunakan rumus di atas maka besarnya a dan b dapat dihitung, yaitu:

$$
\begin{aligned}
& \mathrm{a}=\frac{\sum Y \cdot \sum X^{2}-\sum X \cdot \sum X Y}{\mathrm{n} \cdot \sum X^{2}-\left(\sum X\right)^{2}} \\
& (225.761 \times 55)-(15 \times 679.375) \\
& a=(5 x 55)-(15)^{2} \\
& \mathrm{a}=44524,6 \\
& \mathrm{~b}=\frac{n \cdot \sum X Y-\sum X \cdot \sum Y}{n \cdot \sum X^{2}-\left(\sum X\right)^{2}} \\
& (5 \times 679.375)-(15 \times 225.761) \\
& b=-(5 x 55)-(15)^{2} \\
& \mathrm{~b}=209,2 \\
& \mathrm{Y}_{03}=\mathrm{a}+\mathrm{b} \cdot\left(\mathrm{T}_{03}-\mathrm{T}_{07}\right) \\
& \mathrm{Y}_{03}=44524,6+209,2 .(0) \\
& \mathrm{Y}_{03}=44524,6
\end{aligned}
$$

Dengan cara perhitungan yang sama, hasil perhitungan mundur jumah penduduk perhatikan tabel berikut. 


\section{SANG PENCERAH}

Volume 3, Nomor 2, Agustus 2017, Hlm. 1-10

Agusman: Analisis Tingkat Kebutuhan Air Bersih Wilayah ...

Tabel 3 Hasil Perhitungan Jumlah Penduduk

\begin{tabular}{cllll}
\hline $\begin{array}{c}\text { Tahun } \\
(\text { X) }\end{array}$ & $\begin{array}{l}\text { Statistik } \\
\text { Jumlah } \\
\text { Penduduk (Y) }\end{array}$ & Aritmatika & Geometrik & $\begin{array}{c}\text { Regresi } \\
\text { Linear }\end{array}$ \\
\hline 2013 & 44.720 & 44720 & 44720,71 & 44524,6 \\
2014 & 44.915 & 44918,25 & 44917,48 & 44733,8 \\
2015 & 45.192 & 45116,5 & 45115,11 & 44943 \\
2016 & 45.421 & 45314,75 & 45313,62 & 45152,2 \\
2017 & 45.513 & 45513 & 45513 & 45361,4 \\
\hline Jumlh & 225.761 & - & - & - \\
\hline
\end{tabular}

Sumber : Hail Analisis

Selanjutnya hasil standar deviasi perhitungan Aritmatika, Geometrik, dan Regresi Linear dapat dilihap pada Tabel.

Tabel 4 Standar Deviasi Perhitungan Aritmatika

\begin{tabular}{llllll}
\hline Tahun & $\begin{array}{l}\text { Tahun } \\
\text { ke }(\mathbf{X})\end{array}$ & $\begin{array}{l}\text { Statistik } \\
\text { Jumlah } \\
\text { Penduduk }\end{array}$ & $\begin{array}{l}\text { Perhitungan } \\
\text { Aritmatika } \\
\left(\mathbf{Y}_{\mathbf{i}}\right)\end{array}$ & $\mathbf{Y}_{\mathrm{i}-\mathbf{Y}_{\text {mean }}}$ & $\left(\mathbf{Y}_{\mathrm{i}}-\mathbf{Y}_{\text {mean }}\right)^{2}$ \\
\hline 2013 & 1 & 44.720 & 44.720 & -432 & 186.797 \\
2014 & 2 & 44.915 & 44918,25 & 234 & 54.733 \\
2015 & 3 & 45.192 & 45116,5 & 36 & 1.274 \\
2016 & 4 & 45.421 & 45314,75 & 136 & 26.423 \\
2017 & 5 & 45.513 & 45513 & 361 & 130.177 \\
Jumlah & 15 & 225.761 & - & - & 399.403 \\
ymean & - & 45152,2 & - & - & - \\
\hline Standar & - & - & - & - & $\mathbf{2 8 2 , 6 3 1}$ \\
Deviasi & & & & & \\
\hline
\end{tabular}

Sumber: Hasil Analisis

Tabel 5 Standar Deviasi Perhitungan Geometrik

\begin{tabular}{llllll}
\hline Tahun & $\begin{array}{l}\text { Tahun } \\
\text { ke } \mathbf{( X )}\end{array}$ & $\begin{array}{l}\text { Statistik } \\
\text { Jumlah } \\
\text { Penduduk }\end{array}$ & $\begin{array}{l}\text { Perhitungan } \\
\text { Geometrik } \\
\left(\mathbf{Y}_{\mathbf{i}}\right)\end{array}$ & $\begin{array}{l}\mathbf{Y}_{\mathrm{i}^{-}} \\
\mathbf{Y}_{\text {mean }}\end{array}$ & $\begin{array}{l}\left(\mathbf{Y}_{\mathbf{i}^{-}}\right. \\
\left.\mathbf{Y}_{\text {mean }}\right)^{2}\end{array}$ \\
\hline 2013 & 1 & 44.720 & 44720,71 & -431 & $\begin{array}{l}186.18 \\
7\end{array}$ \\
2014 & 2 & 44.915 & 44917,48 & -235 & 55.095 \\
2015 & 3 & 45.192 & 45115,11 & -37 & 1.375 \\
2016 & 4 & 45.421 & 45313,62 & 161 & 26.056 \\
2017 & 5 & 45.513 & 45513 & 361 & 130.17 \\
Jumlah & 15 & 225.761 & - & - & 7 \\
ymean & - & 45152,2 & - & - & 1 \\
\hline Standar & - & - & - & - & $\mathbf{2 8 2 , 4 5}$ \\
Deviasi & & & & & 0 \\
\hline
\end{tabular}

Sumber : Hasil Analisis
Tabel 5 Standar Deviasi Perhitungan Regresi Linear

\begin{tabular}{llllll}
\hline Tahun & $\begin{array}{l}\text { Tahu } \\
\mathbf{n} \text { ke } \\
(\mathbf{X})\end{array}$ & $\begin{array}{l}\text { Statistik } \\
\text { Jumlah } \\
\text { Penduduk }\end{array}$ & $\begin{array}{l}\text { Perhitungan } \\
\text { Regresi } \\
\text { Linear }\left(\mathbf{Y}_{\mathbf{i}}\right)\end{array}$ & $\begin{array}{l}\mathbf{Y}_{\mathbf{i}^{-}} \\
\mathbf{Y}_{\text {mean }}\end{array}$ & $\begin{array}{l}\mathbf{( Y}_{\mathbf{i}^{-}} \\
\left.\mathbf{Y}_{\text {mean }}\right)^{2}\end{array}$ \\
\hline 2013 & 1 & 44.720 & 44524,6 & -628 & 393.882 \\
2014 & 2 & 44.915 & 44733,8 & -418 & 175.059 \\
2015 & 3 & 45.192 & 44943 & -209 & 43.765 \\
2016 & 4 & 45.421 & 45152,2 & 0 & 0 \\
2017 & 5 & 45.513 & 45361,4 & 209 & 43.765 \\
Jumlah & 15 & 225.761 & - & - & 656.470 \\
ymean & - & 45152,2 & - & - & - \\
\hline Standar & - & - & - & - & 362,345 \\
Deviasi & & & & & \\
\hline
\end{tabular}

Sumber : Hasil Analisis

Hasil perhitungan standar deviasi memperlihatkan angka yang berbeda untuk tiga metode proyeksi. Angka terkecil adalah hasil perhitungan proyeksi dengan metode Geometrik. Jadi untuk memperkirakan jumlah penduduk Kota Wangi-Wang pada tahun2028 mendatang dipilih metode Geometrik.

1. Berdasarkan Jumlah Penduduk Kota Wangi-Wangi

Perkiraan jumlah penduduk Kota Wangi-Wangi dianalisis dengan menggunakan rumus geometrik dengan data jumlah penduduk yang didapat dari PDAM Kontamale sejak tahun 2017 dengan prediksi hingga tahun 2028. Dengan menggunakan rumus Pn $=$ Po $(1+r)^{n}$

Dengan :

$\mathrm{Pn}=$ Jumlah penduduk pada tahun $\mathrm{n}$ proyeksi.

Po $=$ Jumlah pendudduk apda awal proyeksi.

$\mathrm{r} \quad=$ Rerata pertumbuhan penduduk per tahun.

$\mathrm{n}=$ Waktu (tahun). 


\section{SANG PENCERAH}

Volume 3, Nomor 2, Agustus 2017, Hlm. 1-10

Agusman: Analisis Tingkat Kebutuhan Air Bersih Wilayah ...

Tabel 6 Pertambahan Jumlah Kota WangiWangi

\begin{tabular}{llll}
\hline \multirow{2}{*}{ Tahun } & \multirow{2}{*}{ Jumlah Penduduk } & \multicolumn{2}{c}{ Pertambahan } \\
& & \multicolumn{1}{c}{ Jiwa } & \multicolumn{1}{c}{} \\
\hline 2013 & 44.720 & 195 & 0,436 \\
2014 & 44.915 & 277 & 0,617 \\
2015 & 45.192 & 229 & 0,507 \\
2016 & 45.421 & 91 & 0,200 \\
2017 & 45.513 & 792 & 1,760 \\
\hline Jumlah & & &
\end{tabular}

Sumber: Hasil Analisis

Persentase pertambahan jumlah penduduk:

$$
\begin{aligned}
& \text { r }=\begin{array}{c}
1,760 \\
-
\end{array} \\
& \mathrm{r}=0,44 \% \\
& \text { pertambahan jumlah penduduk dari } \\
& \text { tahun 2013- } 2017 \text { adalah : } \\
& \mathrm{P}_{2028}=\mathrm{P}_{2013}(1+\mathrm{r})^{\mathrm{n}} \\
& =45.513(1+(0,0044))^{11} \\
& =47764,93681 \approx 47.765 \text { jiwa }
\end{aligned}
$$

Berdasarkan hasil perhitungan di atas pertambahan penduduk cenderung bertambah/mengalami kenaikan. Jumlah penduduk Kota Wangi-Wangi tahun 2028 sebesar 47.765 jiwa.

2. Berdasarkan Jumlah Penduduk Daerah Pelayanan Unit Kota Wangi-Wangi

Perkiraan jumlah penduduk daerah pelayanan Kota Wangi-Wangi dianalisis dengan menggunakan rumus geometrik, dengan prediksi hingga tahun 2028, dengan menggunakan rumus.

Tabel 7 Pertambahan Jumlah Penduduk Daerah Pelayanan Unit Kota Wangi-Wangi

\begin{tabular}{llll}
\hline \multirow{2}{*}{ Tahun } & \multirow{2}{*}{ Jumlah Penduduk } & \multicolumn{2}{c}{$\begin{array}{c}\text { Pertambahan } \\
\text { Jiwa }\end{array}$} \\
\hline 2013 & 26.613 & - & - \\
2014 & 26.780 & 167 & 0,627 \\
2015 & 26.803 & 23 & 0,86 \\
2016 & 26.801 & -2 & 0,007 \\
2017 & 26.920 & 119 & 0,444 \\
\hline Jumlah & & 307 & 1,164 \\
\hline
\end{tabular}

Sumber : Hasil Analisis
Persentase pertambahan penduduk :

$$
\begin{aligned}
& 1,164 \\
& r=-- \\
& r=0,291 \%
\end{aligned}
$$

pertambahan jumlah penduduk dari tahun 2017-2028 adalah :

$$
\begin{aligned}
\mathrm{P}_{2028} & =\mathrm{P}_{2017}(1+\mathrm{r})^{\mathrm{n}} \\
& =26.920(1+(0,00291)) 11 \\
& =27794,357 \approx 27.795 \text { jiwa }
\end{aligned}
$$

Berdasarkan hasil perhitungan di atas pertambahan penduduk cenderung bertambah/mengalami kenaikan. Jumlah

\begin{tabular}{|c|c|c|c|c|}
\hline \multirow[t]{2}{*}{ No } & \multirow[t]{2}{*}{ Tahun } & \multirow[t]{2}{*}{ SR } & \multicolumn{2}{|c|}{ Pertambahan Pelanggn } \\
\hline & & & Selisih & $\%$ \\
\hline 1 & 2013 & 147 & - & - \\
\hline 2 & 2014 & 91 & -56 & - 38,095 \\
\hline 3 & 2015 & 154 & 63 & 69,231 \\
\hline 4 & 2016 & 159 & 5 & 3,247 \\
\hline 5 & 2017 & 159 & 0 & 0,00 \\
\hline Juml & & & 12 & 34,383 \\
\hline
\end{tabular}
penduduk daerah pelayanan unit Kota Wangi-Wangi tahun 2028 sebesar 27.795 jiwa.

\section{Prediksi Pertambahan Pelanggan}

Prediksi pertambahan pelanggan PDAM dihitung dengan metode geometrik untuk masing-masing jenis pelanggan, kemudian dijumlahkan sehingga akan diperoleh data yang lebih akurat untuk perencanaan.

\section{Pelanggan Kelurahan Wanci}

Tabel 8 Pelanggan Kelurahan Wanci

Sumber : Hasil Analisis

Persentase pertambahan jumlah pelanggn Kelurahan Wanci :

$$
\begin{aligned}
& \text { 34,383 } \\
& r \text { = ------ } \\
& 4 \\
& r=8,596 \%
\end{aligned}
$$

Pertambahan jumlah pelanggan Kelurahan Wanci dari tahun 2017 -2028 adalah :

$$
\mathrm{M}_{11}=159(1+0,08596)^{11}
$$




\section{SANG PENCERAH}

Volume 3, Nomor 2, Agustus 2017, Hlm. 1-10

Agusman: Analisis Tingkat Kebutuhan Air Bersih Wilayah ...

$$
=393,867 \approx 394 \mathrm{SR}
$$

Berdasarkan hasil perhitungan di atas pertambahan pelanggan Kelurahan Wanci cenderung bertambah/mengalami kenaikan tahun 2028 sebesar 394 SR.

\section{Pelanggan Kelurahan Tindoi}

Tabel 9 Pelanggan Kelurahan Tindoi

\begin{tabular}{|c|c|c|c|c|}
\hline \multirow{2}{*}{ No } & \multirow{2}{*}{ Tahun } & \multirow{2}{*}{ SR } & \multicolumn{2}{|c|}{ Pertambahan Pelanggan } \\
\hline & & & Selisih & $\%$ \\
\hline 1 & 2013 & 909 & - & - \\
\hline 2 & 2014 & 779 & -130 & $-14,301$ \\
\hline 3 & 2015 & 928 & 149 & 19,127 \\
\hline 4 & 2016 & 964 & 36 & 3,879 \\
\hline 5 & 2017 & 1005 & 41 & 4,253 \\
\hline \multicolumn{3}{|c|}{ Jumlah } & 96 & 12,958 \\
\hline
\end{tabular}

Sumber : Hasil Analisis

Persentase pertambahn jumlah pelanggan Kelurahan Tindoi:

$$
\begin{aligned}
& r=\frac{12,958}{4} \\
& r=3,2395 \%
\end{aligned}
$$

Pertambahan jumlah pelanggan Kelurahan Tindoi tahu 2017-2028 adalah :

$$
\begin{aligned}
\mathrm{M}_{11} & =1005(1+0,032395)^{11} \\
& =1427,154 \approx 1428 \mathrm{SR}
\end{aligned}
$$

Berdasarkan hasil perhitungan di atas pertambahan pelanggan Kelurahan Tiondoi cenderung bertambah/mengalami kenaikan tahun 2028 sebesar 1428 jiwa.

\section{Pelanggan Kelurahan Lia}

\section{Tabel 10 Pelanggan Kelurahan Lia}

\begin{tabular}{ccccc}
\hline \multirow{2}{*}{ No } & Tahun & SR & $\begin{array}{l}\text { Pertambahan Pelanggan } \\
\text { Selisih }\end{array}$ & $\%$ \\
\hline 1 & 2013 & 1 & - & - \\
2 & 2014 & 1 & - & - \\
3 & 2015 & 1 & - & - \\
4 & 2016 & 1 & - & - \\
5 & 2017 & 1 & - & - \\
\hline \multicolumn{5}{c}{ Jumlah } \\
\hline
\end{tabular}

Sumber : Hasil Analisis

Berdasarkan Tabel 4.15. di atas pada tahun 2013-2017 di daerah pelayanan Kota Wangi-Wangi hanya terdapat 1 pelanggn

\begin{tabular}{|c|c|c|c|c|}
\hline \multirow{2}{*}{ No } & \multirow{2}{*}{ Tahun } & \multirow{2}{*}{ SR } & \multicolumn{2}{|c|}{ Pertambahan Pelanggan } \\
\hline & & & Selisih & $\%$ \\
\hline 1 & 2013 & 18 & - & - \\
\hline 2 & 2014 & 13 & -5 & - 27,778 \\
\hline 3 & 2015 & 22 & 9 & 69,231 \\
\hline 4 & 2016 & 24 & 2 & 9,091 \\
\hline 5 & 2017 & 24 & - & - \\
\hline & Jumlah & & 6 & 50,544 \\
\hline
\end{tabular}

PDAM jenis Kelurahan Lia, hal ini dapat dikatakan jumlah pelanggan pada tahun 2028 tetap sebesar 1 SR.

\section{Pelanggan Hidran Umum}

Tabel 11 Pelanggan Hidran Umum

Sumber : Hasil Analisis

Persentase pertambahan jumlah pelanggan Hidran Umum :

$$
\begin{aligned}
& r=\begin{array}{l}
50,544 \\
-r=12,636 \% \\
\text { pertambahan jumlahp pelanggan }
\end{array} \\
& \text { r }
\end{aligned}
$$

Hidran Umum 2017-2028 adalah :

$$
\begin{aligned}
\mathrm{M}_{11} & =24(1+0,12636)^{11} \\
& =88,, 851 \approx 89 \mathrm{SR}
\end{aligned}
$$

Berdasarkan hasil perhitungan di atas pertambahan pelanggan Hidran Umum cenderung bertambah/mengalami kenaikan tahun 2028 sebesar 89 jiwa.

Pelanggan Pemerintahan Tabel 12 Pelanggan Pemerintahan

\begin{tabular}{ccccc}
\hline No & Tahun & SR & $\begin{array}{c}\text { Pertambahan Pelanggan } \\
\text { Selisih }\end{array}$ \\
1 & 2013 & 17 & - & - \\
2 & 2014 & 15 & -2 & $-11,765$ \\
3 & 2015 & 17 & - & 13,333 \\
4 & 2016 & 17 & 1 & - \\
5 & 2017 & 16 & -1 & $-5,882$ \\
\hline & Jumlah & -1 & $-4,314$ \\
\hline
\end{tabular}

Sumber : Hasil Analisis

Persentase pertambahn jumlah pelanggan Pemerintahan :

$$
\begin{array}{cc}
r= & -4,314 \\
r & =1,0785 \%
\end{array}
$$

Pertambahan jumlah pelanggan Pemerintahan 2017-2028 adalah: 


\section{SANG PENCERAH}

Volume 3, Nomor 2, Agustus 2017, Hlm. 1-10

Agusman: Analisis Tingkat Kebutuhan Air Bersih Wilayah ...

$$
\begin{aligned}
\mathrm{M}_{11} & =16(1+-0,010785)^{11} \\
& =14,201 \approx 15 \mathrm{SR}
\end{aligned}
$$

Berdasarkan hasil perhitungan di atas pertambahan pelanggan Pemerintahan cenderung berkurang/mengalami penurunan pada tahun 2028 sebesar 15 SR.

\section{Pelanggan Sosial}

Tabel 13 Pelanggan Sosial

\begin{tabular}{ccccc}
\hline \multirow{2}{*}{ No } & \multirow{2}{*}{ Tahun } & SR & \multicolumn{2}{c}{ Pertambahan Pelanggan } \\
\cline { 4 - 5 } & & & Selisih & $\%$ \\
\hline 1 & 2013 & 16 & - & - \\
2 & 2014 & 14 & -2 & $-12,5$ \\
3 & 2015 & 19 & 5 & 35,714 \\
4 & 2016 & 20 & 1 & 5,263 \\
5 & 2017 & 21 & 1 & 5 \\
\hline & Jumlah & & 5 & 33,477 \\
\hline
\end{tabular}

Sumber : Hasil Analisis

Persentase pertambahan jumlah pelanggan Sosial:

$$
33,477
$$

$$
\begin{aligned}
r & =------ \\
r & =8,369 \%
\end{aligned}
$$

Pertambahan jumlah pelanggan Sosial 2017-2028 adalah :

$$
\begin{aligned}
\mathrm{M}_{11} & =21(1+-0,08369)^{11} \\
& =50,836 \approx 51 \mathrm{SR}
\end{aligned}
$$

Berdasarkan hasil perhitungan di atas pertambahan pelanggan Sosial cenderung bertambah/mengalami kenaikan pada tahun 2028 sebesar 51 SR.

\section{Pelanggan Niaga}

Tabel 14 Pelanggan Niaga

\begin{tabular}{ccccc}
\hline \multirow{2}{*}{ No } & \multirow{2}{*}{ Tahun } & \multirow{2}{*}{ SR } & \multicolumn{2}{c}{ Pertambahan Pelanggan } \\
\cline { 5 - 5 } & & & Selisih & $\%$ \\
\hline 1 & 2013 & 5 & - & - \\
2 & 2014 & 3 & -2 & -40 \\
3 & 2015 & 5 & 2 & 66,667 \\
4 & 2016 & 5 & - & - \\
5 & 2017 & 5 & & - \\
\hline & Jumlah & & 0 & 26,667 \\
\hline
\end{tabular}

\section{Sumber: Hasil Analisis}

Persentase pertambahan jumlah pelanggan Niaga :

$$
\begin{aligned}
& r=\frac{26,667}{4} \\
& r=6,667 \%
\end{aligned}
$$

Pertambahan jumlah pelanggan Niaga 2017-2028 adalah :

$$
\begin{aligned}
\mathrm{M}_{11} & =5(1+-0,06667)^{11} \\
& =10,169 \approx 11 \mathrm{SR}
\end{aligned}
$$

Berdasarkan hasil perhitungan di atas pertambahan pelanggan Niaga cenderung bertambah/mengalami kenaikan pada tahun 2028 sebesar 11 SR.

Dari perhitungan prediksi diatas jumlah pelanggan PDAM tahun $2028=$ pelanggan Kelurahan Wanci + Kelurahan Lia + Kelurahan Tindoi + Pemerintahan + Sosial + Niaga $=394+1428+1+89+15+51+11=1989$ SR.

\section{Analisis Terhadap Cakupan Pelayanan Air Bersih}

Cakupan target pelayanan air bersih dari PDAM diambil 80\% jumlah penduduk, adapun $20 \%$ jumlah penduduk diharapkan mencukupi sendiri kebutuhan air bersih dari sumur, mata air dan lain-lain, maka prediksi cakupan pelayanan air bersih PDAM unit Kota Wangi-Wangi pada tahun 2028 adalah :

$$
\begin{aligned}
\mathrm{CP}_{\text {kecamatan }} & =80 \% \times \mathrm{Pn} \\
& =80 \% \times 47.765 \\
& =38.212 \mathrm{jiwa} \\
\mathrm{CP}_{\text {daerah pelayanan }} & =80 \% \times \mathrm{Pn} \\
& =80 \% \times 27.795 \\
& =22.236 \mathrm{jiwa}
\end{aligned}
$$

Prediksi berdasarkan jenis pelanggan

$\checkmark$ Domestik

$$
\begin{aligned}
& \mathrm{SI}=\mathrm{R} 1+\mathrm{R} 2+\mathrm{R} 3+\mathrm{R} 4 \\
& \mathrm{SI}=394+1428+1+0 \\
& \mathrm{SI}=1823 \times 5 \\
& \mathrm{SI}=9115 \text { jiwa }
\end{aligned}
$$

$\checkmark$ Non domestik

$\mathrm{Kn}=$ Niaga + Sekolah + Pemerintah

$\mathrm{Kn}=11+0+15$

$\mathrm{Kn}=26 \mathrm{SR}$

$\mathrm{Kn}=26 \times 6$

$\mathrm{Kn}=156$ jiwa

$\checkmark \quad$ Pelanggan sosial (Sb)

$\mathrm{Sb}=$ Sosial umum + Sosial khusus

+ Hidran umum

$\mathrm{Sb}=51+89$ 


\section{SANG PENCERAH}

Volume 3, Nomor 2, Agustus 2017, Hlm. 1-10

Agusman: Analisis Tingkat Kebutuhan Air Bersih Wilayah ...

$\mathrm{Sb}=(51 \times 50)+(89 \times 25)$

$\mathrm{Sb}=4.775$ jiwa

$\checkmark$ Total jumlah pelanggan pada tahun 2028

$$
\begin{aligned}
\mathrm{Pn} & =\mathrm{S} 1+\mathrm{Kn}+\mathrm{Sb} \\
& =9115+156+4775 \\
& =14.046 \text { jiwa }
\end{aligned}
$$

Cp kota Wangi-Wangi tahun 2028

$$
\begin{aligned}
\% \text { pelayanan }= & 14046 \\
- & 47765 \\
= & 29,41 \%
\end{aligned}
$$

CP daerah pelayanan Kota WangiWangi tahun 2028

$$
\begin{aligned}
& 14046 \\
& \% \text { pelayanan }=\frac{------}{27795} \times 100 \% \\
& =50,53 \%
\end{aligned}
$$

Cakupan pelayanan PDAM pada tahun 2028 baru mencapai 29,41 \% untuk Kota Wangi-Wangi dan 50,53 \% untuk daerah pelayanan unit Kota Wangi-Wangi, sehingga cakupan pelayanan masih dibawah standar nasional yaitu $80 \%$ dari jumlah penduduk.

\section{Analisi Debit Air}

Analisis Kebutuhan Air Bersih Terhadap Kapasitas Produksi Sumber Mata Air Kota Wangi-Wangi. Perhitungan kebutuhan air bersih di unit Kota WangiWangi berdasarkan prediksi masing-masing jenis pelanggan.

Tabel 15 Debit Yang Dibutuhkan Unit Kota

\begin{tabular}{ll} 
& Wangi-Wangi \\
\hline Tahun & Q (liter/detik) \\
\hline 2017 & 9,32581 \\
2018 & 9,761285 \\
2019 & 10,1917 \\
2020 & 10,64887 \\
2021 & 11,1263 \\
2022 & 11,65075 \\
2023 & 12,20052 \\
2024 & 12,76476 \\
2025 & 13,35576 \\
2026 & 14,04297 \\
2027 & 14,73163 \\
2028 & 15,48539 \\
\hline
\end{tabular}

Sumber : Hasil Analisis

\section{Analisis Debit Sumber Mata Air Unit Kota Wangi-Wangi}

Berdasarkan Tabel di atas kapasitas debit sumber Mata Air unit Kota WangiWangi pada tahun 2013-2017 berturut-turut adalah 16,0 liter/detik, dan kapasitas debit pompa berturut-turut adalah 13,0

\begin{tabular}{|c|c|c|c|c|}
\hline Tahun & $\begin{array}{l}\text { Q } \\
\text { Kebutuhan } \\
\text { Air } \\
\text { (liter/detik) }\end{array}$ & $\begin{array}{l}\text { Kapasitas } \\
\text { Sumber } \\
\text { (liter/detik) }\end{array}$ & $\begin{array}{l}\text { Kapasitas } \\
\text { Produksi } \\
\text { (liter/detik) }\end{array}$ & $\begin{array}{l}\text { Kekurangan } \\
\text { Produksi } \\
\text { (liter/detik) }\end{array}$ \\
\hline 2017 & 9,32581 & 16,0 & 13,0 & - \\
\hline 2018 & 9,761285 & 16,0 & 13,0 & - \\
\hline 2019 & 10,1917 & 16,0 & 13,0 & - \\
\hline 2020 & 10,64887 & 16,0 & 13,0 & - \\
\hline 2021 & 11,1263 & 16,0 & 13,0 & - \\
\hline 2022 & 11,65075 & 16,0 & 13,0 & - \\
\hline 2023 & 12,20052 & 16,0 & 13,0 & - \\
\hline 2024 & 12,76476 & 16,0 & 13,0 & - \\
\hline 2025 & 13,35576 & 16,0 & 13,0 & 0,35576 \\
\hline 2026 & 14,04297 & 16,0 & 13,0 & 1,04297 \\
\hline 2027 & 14,73163 & 16,0 & 13,0 & 1,73163 \\
\hline 2028 & 15,48539 & 16,0 & 13,0 & 2,48539 \\
\hline
\end{tabular}
liter/detik. Hal ini dapat diasumsikan kapasitas debit sumber mata air pada tahun 2028 tetap. Kapasitas debit sumber sumber mata air 16,0 liter/detik, dan kapasitas debit pompa 13,0 liter/detik.

Tabel 16 Debit Kebutuhan Air dengan Debit Sumber Mata Air Unit Kota Wangi-Wangi

Sumber : Hasil Analisis

Data kebutuhan air dengan debit sumber mata air unit Kota Wangi-Wangi kemudian di plot titik tertentu yaitu $(28,72 \%$ - 44,53\%) dan mengalami penurunan (40,65\%) berbeda dengan effisiensi overal pada pompa pararel yaitu semakin besar debit air maka effisiensi overalnya semakin besar yaitu (25,65\% - 60,68\%) Pada pompa pararel effisiensi overalnya semakin besar seiring bertambahnya debit air yang dihisap oleh pompa. Hal ini dikarenakan pompa pararel effisiensinya semakin meningkat dengan makin semakin banyaknya debit air berarti kemampuan pompa semakin 


\section{SANG PENCERAH}

Volume 3, Nomor 2, Agustus 2017, Hlm. 1-10

Agusman: Analisis Tingkat Kebutuhan Air Bersih Wilayah ...

bertambah. Hasil penelitian diatas menunjukkan bahwa hasil perhitungan identik dengan hasil yang diadapat pada saat pengambilan data.

\section{Simpulan}

Simpulan penelitian ini bahwa kebutuhan air bersih daerah pelayanan Kota Wangi-Wangi Kabupaten Wakatobi tahun 2028 menurut jumlah penduduk sebesar 31,82 liter/detik, Kebutuhan air bersih menurut prediksi masing-masing jenis pelanggan adalah 15,48 liter/detik. Kekurangan debit pompa produksi yang dibutuhkan untuk memenuhi kebutuhan air bersih wilayah Kota Wangi-Wangi Kabupaten Wakatobi pada tahun 2028 adalah sebesar 2,48 liter/detik.

\section{Daftar Pustaka}

Anonim. 2007. Buku Pedoman Penulisan Tugas Akhir dan Kerja Praktek Jurusan Teknik Sipil Fakultas Teknik Universitas Muhammadiyah Buton, Baubau.

G. D. Steel Robert \& H. Torrie James, 1993 Prinsip dan Prosedur Statistika. Jakarta: Gramedia.

Indra Kusuma Sari, Lily Montarich Limantara dan Dwi Priyantoro. 2007. Analisis Ketersediaan dan Kebutuhan Air Pada DAS Sampean". Hasil penelitian yang tidak dipublikasikan.

Marhadiyanto D.D. dan Suprihando N. 2009 Studi Pemenuhan Kebutuhan Air Bersih Dengan Sistem Penampungan Air Hujan Di Pulau Panggang. Hasil penelitian yang tidak dipublikasikan.

Masombe, Novriyan. 2015. Perencanaan Sistem Pelayanan Air Bersih Di Kelurahan Bonkawir Kabupaten Raja Ampat Provinsi
Papua Barat. Skripsi Program S1 Jurusan Teknik Sipil Universitas Sam Ratulangi, Manado.

Mugijantoro. 1992, Air Untuk Kehidupan Manusia, Majalah Air Minum, edisi No.85 / th. XXV Oktober 2001

Sutapa, I Wayan. 2009. Studi Potensi Pengembangan Sumber Daya Air Di Kota Ampana Sulawei Tengah. Hasil penelitian yang tidak dipublikasikan. 